\title{
The Design and Practice of Library Maker Service in Shenyang Normal University
}

\author{
Yu Wang, Library of Shenyang Normal University, China \\ Shuli Fan, Library of Shenyang Normal University, China \\ Ziling Cheng, Library of Shenyang Normal University, China
}

\begin{abstract}
Library maker services are a current focus of the industry's theoretical research and practice. With the popularization of the maker movement and the development of "mass entrepreneurship and innovation" in China, the library has been forced to re-examine itself and seek new development opportunities and spaces. Based on the experience of library maker service activities both at home and abroad, this paper explores the design of the library space transformation and the practice of the maker services in Shenyang Normal University. In the face of "mass entrepreneurship and innovation" and the background of education, library maker services have become the main melody, and the construction of makerspaces is the panacea to boost the development of library services. Every qualified library needs to be transformed, insufficient ones need to be reformed, and maker services are not only a development drive of the era, but also the essential path to the future.
\end{abstract}

\section{KEYWORDS}

Library, Maker Services, Mass Entrepreneurship and Innovation, Spatial Transformation

\section{INTRODUCTION}

Maker activity first appeared in the United States. "Makers" are a group of people who are enthusiastic about creating, designing and manufacturing. They are willing, energetic, enthusiastic and capable. Maker activities need places, so "makerspace" was born. The Maker Magazine in the United States defined makerspace as: "a real physical space, the open and exchange fablab, makelab and techshop with the function of processing workshop and studio. Artists, designers, masters of software and hardware and almost anyone, can use the machine and material to put the idea into reality" (Hongli Zhang \& Fenfang Cao,2015). The maker activity soon developed into a nationwide maker movement, which is valued by various fields, such as government, schools and enterprises. In 2012, president Obama launched a government program that would allow more than 1,000 U.S. schools over the next four years to create makerspaces with digital manufacturing tools such as $3 \mathrm{D}$ printers and laser-cutting machines. In the same year, president Obama signed the Promotion of Entrepreneurship Financing Act and the Employment Act to promote the emergence of more public financing platforms and provide financial support for mass innovation and creative inventions (Lili Ma,2014). Thus, the American maker movement became known to the world.

The introduction of the maker movement magically fits the "mass entrepreneurship and innovation" of the national economic development policy put forward by the Chinese government. In September 2014, Premier Keqiang Li made a clear call for "mass entrepreneurship and innovation". In 
February 2015, the State Council Executive Meeting clearly formulated a series of policies to support the development of makerspaces, which created a good policy environment and development platform for innovation and entrepreneurship at the national level. In March 2015, "mass entrepreneurship and innovation" was written into the Chinese government work report. Under the guidance of the national macroeconomic policy, all kinds of makerspaces have sprung up, showing a flourishing developmental trend, which has played a positive role in promoting and leading innovation and supporting entrepreneurship.

\section{LIBRARY REFORM UNDER THE BACKGROUND OF "MASS ENTREPRENEURSHIP AND INNOVATION"}

\subsection{Library and Maker Space}

With the development of a new generation of Internet search engines and electronic information, the library is actively responding to many challenges. By rebuilding or creating a makerspace, the library carries out cultural maker activities and enters into a new and positive era. 2015 the US Library Status Report pointed out that makerspaces are becoming an important trend in the continuous development of the library business, and they have broken the traditional concept that the collection of books is the center of a library (National Library Research Institute, 2015). Among the six kinds of technologies listed in the New Media Alliance Horizon Report (2015 library edition), the "makerspace" is considered the technology that will be adopted in the near future (New Media Alliance (NMC), 2015). The founder of the Maker Magazine D. Dougherty says the maker movement has come to the library; it is not a simple introduction of a 3D printer. Its core aim is to bring the creative concept to the library so that each participant is more passionate to learn new skills and new knowledge. The makerspace is essentially a combination of knowledge, practical experience and its derivatives" (Lei Tao, 2013).

In 2016, the Ministry of Education of China issued The 13th Five Year Plan of Educational Informationization to put forward a clear request and a plan for the innovation of entrepreneurship education in colleges and universities, which has become the responsibility and mission of the library. Accordingly, the library must change their traditional modes of service and a create makerspace. First, it is a significant path towards achieving the transformation of library services. The first and the second generation of library activities centered around the word "book." The future of the third generation library will pay more attention to human needs, accessibility, openness, ecological environment and resource integration, and will be committed to promoting the flow of knowledge, innovation and environments of exchange, while paying attention to multiple elements and stimulating community vitality (Jianzhong $\mathrm{Wu}, 2016$ ). Second, maker spaces are an important way to enhance the core competitiveness of the library. The library carries out the "practice, sharing and innovation" which is the core of the maker service, and an inherent requirement of the library's core mission under the environment of the "mass entrepreneurship and innovation." It is a new mode of knowledge service based on hand-making, knowledge sharing and knowledge creating. Third, makerspaces are an important method to fulfill the library's educational functions; the library carries out the Maker Salon, Creative Seminars, Creative Road Show, Practical Courses, Handcraft, 3D Printing and other activities, which highlights the makers' core qualities of interest-driven and hands-on practice, creative innovation, integration of cross-disciplinary knowledge and STEAM educational concepts. Students can cultivate the spirit of innovation and the practical ability to promote the growth of innovative, entrepreneurial talents.

\subsection{Reform of the Library Maker Service}

The rapid development of the maker movement has promoted the continuous change of various types of library services, and the public libraries have been influenced first. Shanghai Library took the lead in establishing of a "creative-new space" of the makerspace. The theme is cultural and creative, and 
the main purpose is to "activate creativity, exchange knowledge." The carrier is all kinds of innovative activities. This is supported by the collection of literature, digital technology and innovative tools which aim to create a new space for readers to enjoy culture, experience advanced technology, access to the creative inspiration of learning and exchanging and share information. Shenzhen issued the Measures to Promote the Development of Makers (Trial) and the Three-Year Action Plan (2015-2017), and invested 200 million Yuan maker fund to create an international maker center.

University libraries also implement the reform. Under the impetus of the "mass entrepreneurship and innovation", many university library makerspaces have already carried out a variety of maker services. 1) Shanghai Jiao Tong University Library made use of containers to build the "University--Jingdong Maker Space" which is a new type of integration communication space makerspace that provides a creative training base, a 24 hours reading room and other functions; it can bring the teachers and students to share resources on entrepreneurial platform. (2) "Changrong Jianhao Cultural Maker Space" at Tianjin University Library provides students with an open, self-service platform that integrates the innovative and entrepreneurial, online and offline, and incubation and investment. (3) The makerspace of Wuhan University Library provides free audio and video equipment, a conference venue, and roadshow and exhibition platform for college students to innovate social practice and cultural exchange activities. (4) The "Under the Tree Maker Space" of Peking University is jointly built and shared by teachers and students. It advocates openness, exchange, mutual assistance and progress, and provides a collaborative learning environment for group discussions and academic sharing.

\section{DESIGN OF THE MAKER SPACE SERVICE OF SHENYANG NORMAL UNIVERSITY LIBRARY}

The reformation of makerspaces and the services of university libraries can't be all the same. Different schools have different education goals, so the content of their library maker services must be different. Each library's space renovation and service should be based on the education training target of their school, so the mode of maker service has its own characteristics. Taking the practice of maker services in the library of Shenyang Normal University as an example, the author explores the practices of the library maker services of education colleges and universities.

\subsection{Brief Introduction of the Library of Shenyang Normal University}

Shenyang Normal University (SNU) is located in Shenyang, Liaoning province, and organized and directed by Liaoning Province People's Government; it is a multiversity university with departments of philosophy, economics, law, education, literature, mechanics, engineering, management science, art and other categories. With a total area of 21,586 square meters, SNU Library constantly strengthens the collection of physical resources and electronic resources. At present, SNU Library has more than 1.355 million Chinese and foreign books, more than 3200 Chinese and foreign journals, and more than 250,000 electronic books. In addition, SUN library readers can use various Chinese or foreign databases, and the multimedia, multilingual, multidisciplinary and outstanding professional characteristics of school literature center in the library. There is a Main Document Construction Department, Cataloguing Department, Circulation Department, Reading Department, Technology Department, Consulting Department, and Reading Promotion Department among others. The library serves not only teachers and students from the SNU but also the public.

\subsection{Innovation Service System and Space Reconstruction Framework}

SNU library leaders keep up with the development of the era; they make service innovation fundamental for library development. They believe that given the background of "mass entrepreneurship and innovation", service innovation should focus on the innovation of service systems and traditional space transformation, so after many discussions and arguments between the school and the library, the framework of service innovation has set six key aspects from which subversive service reform will 


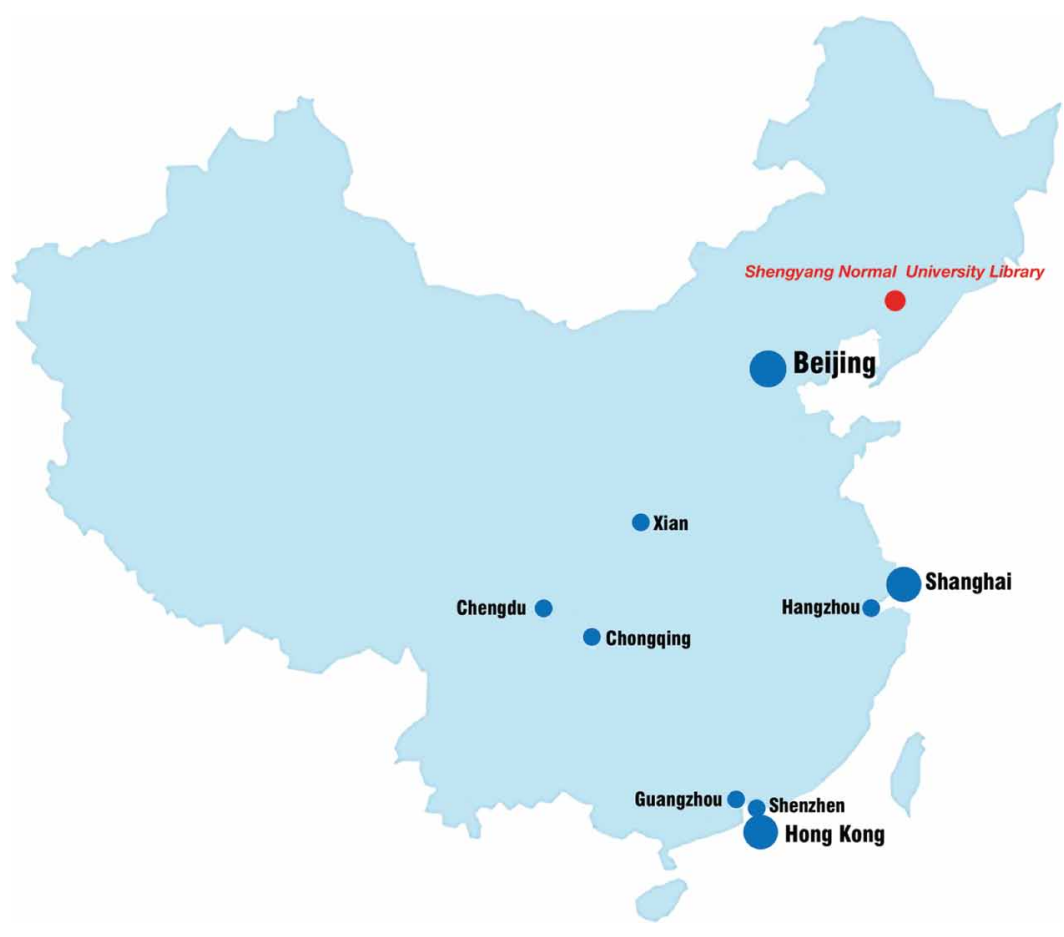

continue to be carried out: service culture, service concept, service objective, service mode, service environment and service system. The blueprint for reform and construction calls for one space for studying and shared space, two platforms (a resource protection platform and a technical support platform), three centers (an academic service center, a humanities quality development center, and an information literacy education center), four positions (people-oriented and readers' home, knowledge services and the second classroom, information leading and shared space, and cultural heritage and spiritual homeland), five domains of support (teaching reform support, discipline construction support, scientific research innovation support, quality improvement support, service society support) and six measures of success (strengthen the cultural heritage, enhance the quality of the librarians, optimize the collection system, enhance the technical strength, promote the environmental construction, and innovate the service content)

\subsection{Innovation Service System and Space Reconstruction Mode}

After establishing a program of library innovation services and the space reconstruction, the key to implementation is funds-raising. Fortunately, the issue of funds has been solved by university funding, because of the demonstration jointly conducted with the university. Within five years, since 2012, the library spent 5 million yuan on total of 5 phase renovation projects, and completed 5 types and a total of 15 space constructions. In the next two years, the library plans to complete a Classic Reading Room, a Picture-books Reading Workshop, a New Books Room, a Tea Cultural Experience Space and a Calligraphy Culture Experience Space.

\subsubsection{Study and Discussion Space}

The Study and Discussion Space includes a Readers Discussion Room with a total of 6 research rooms of different sizes, which can accommodate 8 to 20 people respectively. Each room has computer(s), 
Figure 2. Studying and shared space transformation framework of SNU Library

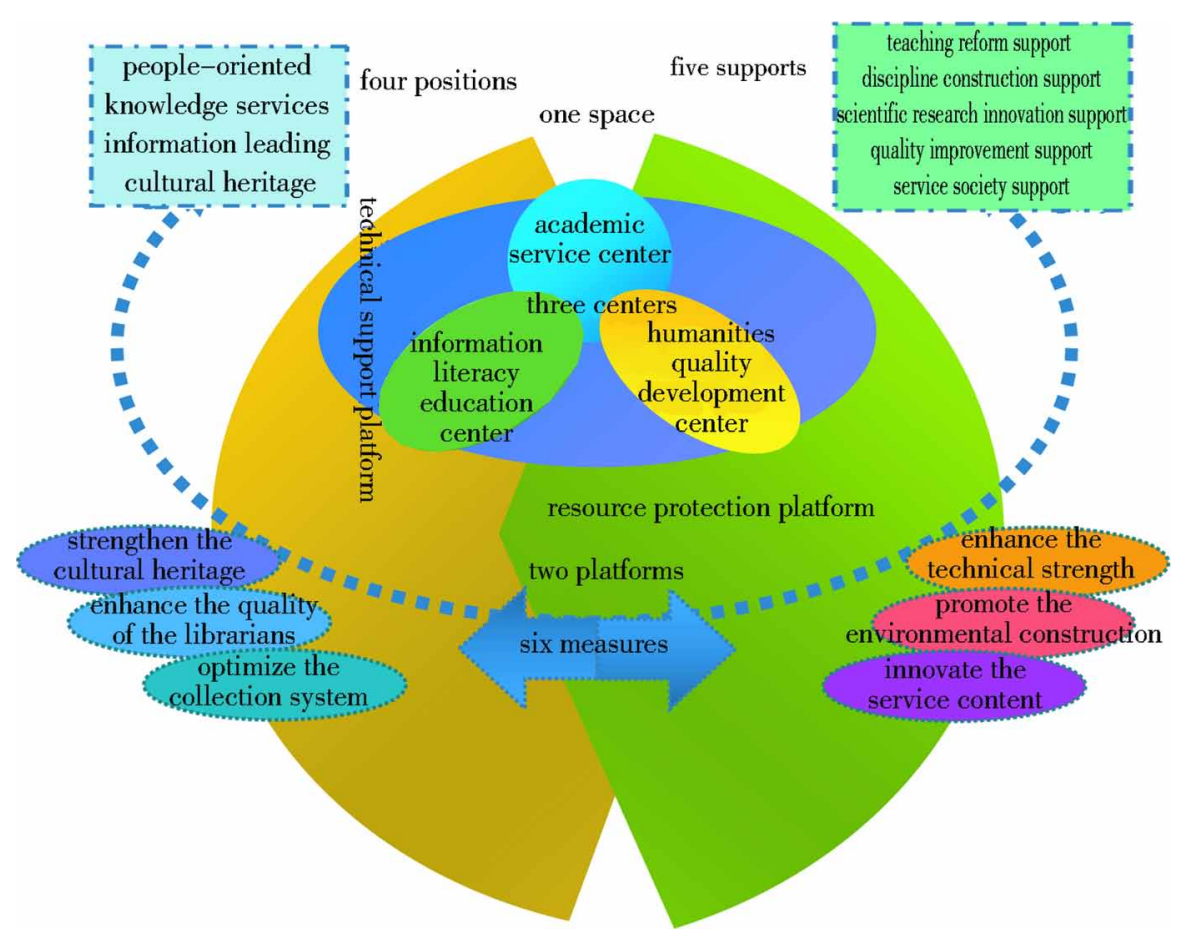

network interfaces, a projector, an electronic drawing board, a white board and other equipment which are convenient for group discussions, academic exchanges, teaching, research, club activities, class meetings, salons, competitions, etc. Readers can use these discussion rooms by making an appointment online. The Study and Discussion Space also includes a Language Communication Space. From 6 to 8 p.m. friday nights, the Library Readers Association will organize foreign students or students from the School of Foreign Languages to communicate with each other in English, which improves readers' interest in learning English, their spoken English, language expression and communication ability, and make learning English easier and more fun.

\subsubsection{Information Literacy Education Space}

The Information Literacy Education Space includes a Writing and Guiding Space and the Information Literacy Training Space. The Writing and Guiding Space provides digital resource and power points of guiding courses, professional essay writing guidance books, various Chinese and English reference books, etc. Readers can make an appointment online for this space and ask a professional teacher to guide their thesis and paper writing, or ask the library teacher to guide readers in a group or in a oneon-one format. The Information Literacy Training Space has a total of three training classrooms. Each training room has teacher computer, student computers and a projector, it can be used to carry out entrance education for freshmen, literature information retrieval courses, database training, embedded teaching, topic training and other information literacy education curriculums.

\subsubsection{Reading Space}

Reading Space includes four spaces. (1) The Digital Reading Space has three components. First is the Video Space, which plays special recommended films freely each week. It provides a multimedia training course for free, and teachers and students hold film and television salons, seminars, etc. 
Second is the Music Appreciation Space which provides a variety of music resources for teachers and students. Readers can enjoy music, study music theory, practice playing, practice music listening, and feel the charm of graceful art. Third is the Classical Recitation Space, which relies on the space recommended in classic articles to invite readers to read together and to listen attentively. (2) The Classic Reading Room, has advanced equipment, perfects all kinds of classic resources, sets up a classic reading system, recommends classic works to all the students with multi-channel and all round services, and guides students to enjoy reading classic masterpieces. (3) The Picture-books Reading Room is a themed venue space which mainly collects objects and service carriers. The Picture-books Reading Room is the practical base of the Preschool Education Department, which is needed for the construction and development of kindergarten. It is the choice of library innovation service in normal colleges and universities. (4) The New Book Workshop will be a platform for the display of all the new books, a place for series of book reviews, lectures, salons, new book conferences, the author's meeting and other activities.

\subsubsection{Maker Space}

The establishment of the maker spaces is the core of the library space transformation; it is a real physical space where the teachers and students can get together to teach and learn, communicate, think, and create. The library has divided this maker space into seven functional spaces. (1) The Maker Gasoline Station handpicks frontier books and periodicals in creation and entrepreneurship. It is equipped with e-readers, selected high-quality electronic resources and provides resources and information which support innovation and entrepreneurship. (2) The Makers Lecture Hall will invite entrepreneur elites and entrepreneurial tutors to carry out "mass innovation and entrepreneurship" guidance for students who want to start a business, and to widen readers' horizons, and to enlighten their thoughts. (3) The Creative Discussion Area encourages college students to discover excellent ideas through sharing, interacting and brainstorming, and discusses how to make ideas come true through a complete process. (4) The Creative Exhibition Area provides readers with the space to display learning outcomes, scientific research results and creative works. (5) The Video Editing Space is equipped with a nonlinear editing system, video cameras, printers, scanners, and CD writers; readers can learn and practice image processing, audio and video editing, web production, statistical analyses, programming languages, etc. (6) The Recording Space of MOOCs is equipped with advanced recording equipment and editing tools; the readers can carry out recording and editing of MOOCs. (7) The New Function Experience Space has digital application terminal experience services that provide the latest digital devices.

\subsubsection{Cultural Display Space}

In order to give an opportunity to show the innovation outcomes and to create a cultural showing and sharing platform for culture exhibition, cultural exchange and cultural experience, the Culture Display Space includes three spaces. (1) The Culture Exhibition Hall: its core is study, creativity, innovation and entrepreneurship, using advanced tools and exhibition which show all teachers and students the teaching reform outcomes, the latest scientific research achievements, and displays various kinds of creative works. (2) The Tea Culture Experience Space: the tea ceremony is a kind of life art, life etiquette and life style. Through the lectures of the Tea Culture Experience Space, teachers and students of SNU will study about the tea ceremony, learn about the etiquette, appreciate the traditional virtues, and improve the skills in students' lives. (3) The Calligraphy Cultural Experience Space: Calligraphy is a unique cultural aspect of Chinese classical art. It is a unique art form and language in the world. It needs to be inherited and carried forward. This space conducts lectures, exchange and display activities, and to achieve a variety of outcomes, such as the essence of calligraphy culture, learning calligraphy skills, and practicing calligraphy. The maker culture of the college teachers and students need a display platform, so the library provides the platform and makes it excellent to expand the influence of culture, and expand the school "mass innovation and entrepreneurship" outcomes. 
Figure 3. Shared space transformation form of SNU Library

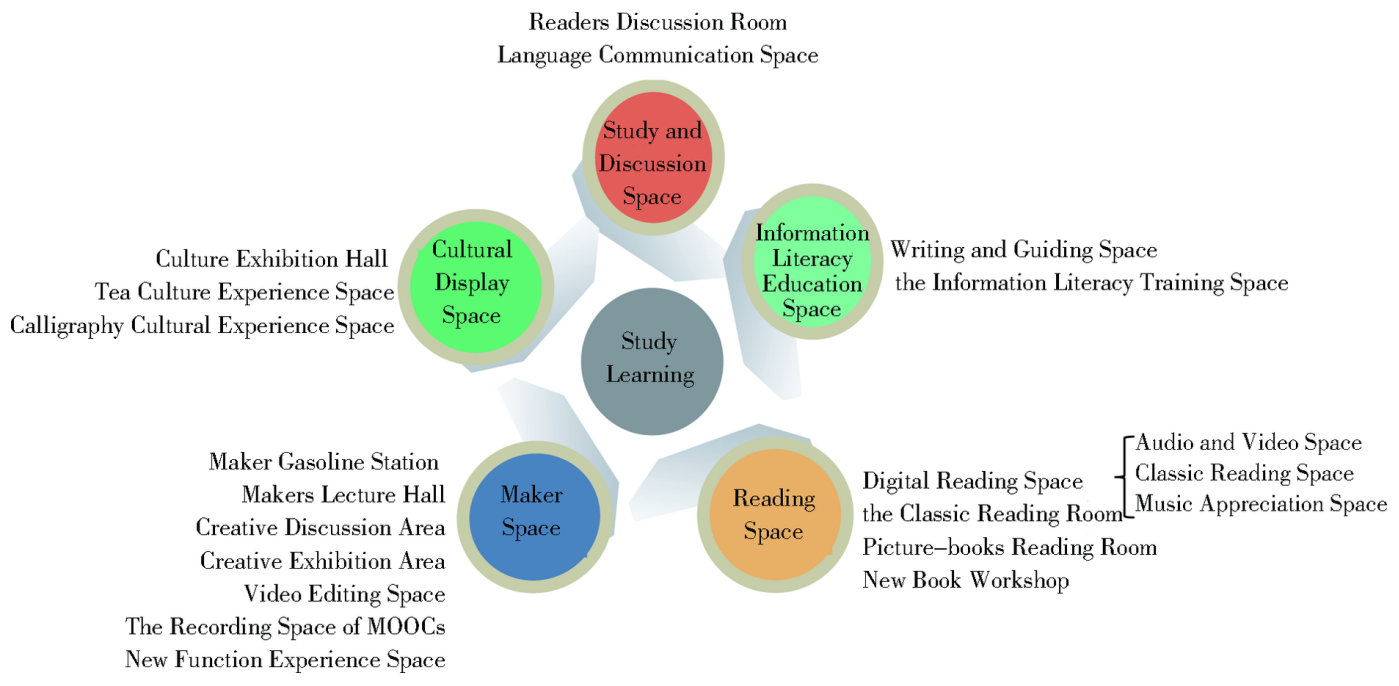

\section{PRACTICE OF THE LIBRARY MAKER SPACE SERVICE OF SHENYANG NORMAL UNIVERSITY}

The spatial transformation of library is not a kind of furnishing, nor chasing fashion fame. The makerspace recycling is a service innovation concept, and an enterprising education. Its essence is to develop skills education; it is not only to design and transform the space from enterprise, but also the importance of how to develop and utilize the space services, and design a variety of activities scientifically, to make contribution to developing skills education for the school.

\subsection{Embed Innovative and Entrepreneurial Education and Cultivate Innovative and Entrepreneurial Quality}

\subsubsection{Information Quality Training}

The cultivation of the quality of science and information is one of the core tasks of library reader services. In order to guide readers to enhance their ability to judge information quality, the library staff woks hard to design various activities to achieve information literacy. For example, the activity "Science and information quality elite training camp", has the following procedure: (1) Look for scientific researchers - recruiting training campers, who can enroll voluntarily. (2) Scientific research sailing dream - the opening ceremony of training camp. (3) Know the real situation of strengths and weaknesses- the entrance examination and questionnaire survey. (4) Scientific research service stationthe full spectrum of progressive campers training. (5) The opening report - The Dean of College of Liberal Arts, Professor Hu Yuwei gives the first report to campers. (6) Research face to face - the chief editor Zhao Wei from the editorial office of School Journal giving the special report "Editorial Norms and Thesis Writing" to campers. (7) Scholar sharing session - the young teachers, scholars and campers interact to exchange learning and research experience. (8) Writing training course subject librarians train campers in related information retrieval and thesis writing skills. (9) Visiting experience class - campers visit Liaoning Provincial Library and Liaoning Science and Technology Museum. (10) Sharing the feelings of each participant - all campers take part in the activities agreed during the "training camp," which are practical and splendid, and relieve confusion; in the process campers opened up the "Sunshine Avenue" of study and creation, and inspire campers to pursue their dreams and work towards their goals. 


\subsubsection{Humanistic Promotion}

The library not only enhances the quality of information available to makers, but also pays attention to the cultivation of humanistic quality and running the humanistic quality of makers' education through a variety of services, such as the "Entrepreneurship · Enjoy Reading" reading cultural festival activity. The $7^{\text {th }}$ Reading Cultural Festival was held in Shenyang Normal University in 2016, and its theme was "Entrepreneurship - Enjoy Reading". The plate of "Entrepreneurship" focused on innovation and entrepreneurship to launch 6 items, including an entrepreneurship auditorium, entrepreneurship reality show, entrepreneurship class, visiting Pioneer Park, initial experience of innovation and creativity collection and over 10 activities. All of these created a strong atmosphere of campus innovation and entrepreneurship. Another example was the "Keep ingenuity, and learn the way of being teacher" theme reading activity. In order to better understand the "craftsman's spirit" proposed by Premier Li Keqiang in the 2016 "Government Work Report" (Baidu encyclopedia, 2016), and thoroughly implement the requirements of "carrying forward the spirit of the craftsman" proposed by General Secretary Xi Jinping, the library must make students understand that mastering the profession and dedication are the cores of the wisdom and spirit of a craftsman. This essence emphasizes the spirital, quality and value orientation of devotion, constantly striving for perfection and the pursuit of excellence (Heilongjiang People's Government, 2016). Through planning the "Keep close ingenuity, and learn the way of teacher" theme reading activity, the library carried forward the "craftsman's spirit" among the college readers, and advocated devotional, rigorous, meticulous, focused, accurate, and innovative professionalism. This activity was accomplished in three steps of reading, viewing and sharing. The first step was reading, including the "craftsman's spirit" theme book exhibition and "the extreme way - I read craftsman's spirit" reading salon. The second step was viewing, including "one day one film, one craftsman one heart" theme film festival, which played seven films such as Masters in the Forbidden City and so on, and collected quotations from articles. The third step was sharing: the reality of the library activity was to share paper-cutting skills by $\mathrm{Bu}$ Yue's team, which provides playing and teaching aids, and the speech "Originality, the way to be a teacher: my career 'as a teacher" ' by Professor Liu Zhaowei, a well-known educational expert in China was given at the forum. The library contains information quality and humanistic quality in all kinds of maker service activities.

\subsubsection{Vocational Skills Training}

Students' vocational skills training is also a core of the content and responsibility of library maker services. All the related activities are based on cultivating professionalism and vocational skills, and various maker services are carried out according to the different majors and disciplines of a normal school. (1) Editorial video production skills training: this is a popular type of skill training, which encourages readers to experience the full scope of video editing and production through the micro-film competition; photography class and photography contest to improve the shooting skills of makers. (2) Embed innovative and entrepreneurial courses: six librarians became the teachers of the course The Foundation of Innovation and Entrepreneurship in 2016; they offered innovative and entrepreneurial education training courses combined with teaching observation to more than 500 readers, to embed innovative and entrepreneurial skill training into document examination courses. (3) Participated in the grant projects: the library set up a grant project team to participate in all levels of innovative and entrepreneurial project competitions for college students. The library has guided 2 provincial projects and 6 school-level projects, among which an entrepreneurial practice project the "Young Dreamer Base," which was guided by the librarians, won the bronze medal of Liaoning Province College Students Entrepreneurship Competition "Entrepreneurship" in 2016. All the rest have been approved by the school. (4) "Characteristic skills" training series: plenty of activity series for training in characteristic skills were carried out, such as ancient books protection, photography, paper-cutting, tea ceremony, bartending, calligraphy, costume design, modeling, etc., to cultivate various skills and innovative awareness for college students. 


\subsection{Share Innovative Ideas to Lead in the Entrepreneurial Direction}

The library has carried out rich and colorful innovation and entrepreneurship services through the "Entrepreneurship Auditorium" since 2016. The library has invited innovative and entrepreneurial teachers and entrepreneurial masters to be guests of the "Entrepreneurship Auditorium", where they share innovative ideas and entrepreneurial sentiment face to face with the students with different identities, experiences and industries and explore different feelings and experiences, to guide innovative and entrepreneurial ideas and direction for the students.

\subsubsection{The Opportunities and Challenges of New Industrial Revolution}

The $7^{\text {th }}$ Reading Cultural Festival "Entrepreneurship" had several innovation and entrepreneurship themed activities. The "Entrepreneurship Auditorium" first report was a shock when it was given in Shenyang Normal University on April 21, 2016. Liu Qi, the famous entrepreneur, President of Canada PQI Industrial Technology Co., Ltd., and co-founder of SOPIN, was invited to the library, and gave a wonderful report entitled The Opportunities and Challenges of New Industrial Revolution for teachers and students. He explained the entrepreneurial outlook in the new era using the changes from industry 1.0 to industry 4.0 as a clue, and included his own entrepreneurial experience and life perception in the report. He also interacted with the students; when talking about the "North drift" problem, he pointed out that "drift" is not important, as long as you are ambitious, and strive to build your own ship, and you can sail anywhere. The wonderful speech of President Liu Qi and his extensive knowledge and earnest teachings provided useful suggestions to the more than 300 teachers and students present.

\subsubsection{Self-Knowledge and Innovation in the Future}

During the $7^{\text {th }}$ Reading Cultural Festival "Entrepreneurship" series of activities, the "Entrepreneurship Auditorium" activities were held in the AV Studio of the Library on April 26 $6^{\text {th, }}, 2016$. Professor Wang Xueying, the Entrepreneurship Instructor from National College, Global Career Development Facilitator (GCDF), committee member of Liaoning Provincial Innovation and Entrepreneurship Education Steering Committee, was invited to give a special report on Self-knowledge and Innovation in the Future for the students. He explained the entrepreneurial concept and entrepreneurial ideas of the new era in the report. Professor Wang Xueying pointed out that, "life is the source of creation; problems are the mother of discovery; learning is the solution; argument is the way to achieve; innovation is the way of life. The fundamental of innovation is to know ourselves and understand our own interest and expertise." He provided advice for the future employment and career choices of students. More than 400 students have benefited from the report, which brought the "Entrepreneurship" series of activities to a climax.

\subsubsection{Pragmatic Innovation, Reliable Entrepreneurship}

In order to improve the awareness and ability of college students in regards to innovation and entrepreneurship, the library invited Mr. Yuan Zhizhong, a researcher of the Chinese Academy of Social Sciences with more than 20 years of experience in direct investment, fund operation and management, to come to the library lecture hall. He gave an interesting report entitled Pragmatic innovation, reliable entrepreneurship to over 300 teachers and students of Shenyang Normal University. In the report, he explained the entrepreneurial outlook and ideas in the new era for makers. Mr. Yuan Zhizhong instructed about investment and financing, entrepreneurship and incubation, pragmatic and innovative methods, risk control and so on with a profound theoretical basis, citing a large number of cases, so as to warn the students that "innovation should be pragmatic, and entrepreneurship should be reliable". His speech had a strong educational inspiration and guiding significance and played a positive role in promoting the innovative and entrepreneurial quality of the students and leading the entrepreneurial direction. 


\subsubsection{Entrepreneurship is to Make Life Blossom}

In order to enable students to expand their horizons and share entrepreneurial ideas and wisdom, the library also invited Wu Dasheng, the President of Beijing Tourye Tourism Culture Co., Ltd. to give the report Entrepreneurship is to make life blossom. Mr. Wu shared his entrepreneurial process with the students from the development of outdoor tourism to the breakthrough point. He gave up a high-paying job to start a business; difficulty did not defeat him, and he finally succeeded. He used his entrepreneurial experience to warn the students to be diligent in self-criticism, to have the courage to admit their mistakes without making the same mistakes again, and to be ready to meet opportunities. He also suggested that students should do adequate research and preparation from the four aspects of: the model, the product, employing and operating when starting a business. His talk was full of life philosophy, and Mr.Wu gave advice by using his own experience as an example to explain the entrepreneurial spirit of the new generation, which obtained positive responses from the teachers and students.

\subsubsection{The Barilla Bookstore of Young Entrepreneurs}

It has always been a profound intention of the library to invite reporters for "Entrepreneurship Auditorium" activities. The library invited an entrepreneurship representative of the post-90s generation of students--the CEO of Beijing Haoheng Zhengtu Aviation Technology Co. Ltd. Chu Zheng, who gave an entrepreneurial reality show The Barilla Bookstore of Young Entrepreneurs to the students of Shenyang Normal University. He explained to the students that it was better to be a doer than a dreamer using his own experiences of study, aid education, entrepreneurship and more. Based on his experiences he leaned the sentiments and entrepreneurial philosophy that he shared with the students: "do not believe in statistics, only calculus",starting a business is not a matter of luck, but a matter of long-term accumulation of basic skills. Chu Zheng believes that young entrepreneurs can activate entrepreneurial genes using five aspects: the accumulation of basic skills, the ability to master fast learning, the development of teamwork, accountability and self-control. One of his sayings, "all the business should be respected", had a strong resonance with the students at the scene.

\subsection{Relying on the Maker Space to Build an Innovative and Entrepreneurial Platform}

\subsubsection{The Innovative and Entrepreneurial Teaching Service Platform}

A makerspace is a real physical space that it is necessary for the library to assist with "innovative and entrepreneurial" education. It should be fully functional, and open and have communicative study rooms, seminar rooms, studios, a laboratory, a works processing room and an achievement exhibition space. The Library relies on a variety of functions of the makerspace to create an innovative and entrepreneurial education atmosphere. First, make the innovative and entrepreneurial thinking everywhere and whenever, and then make everyone take part in innovation teaching activities. Have the makerspace exist everywhere to establish a great platform for innovative and entrepreneurial services in teaching and research. This platform takes "innovation and entrepreneurship" as the core, and carries out the functions of teaching and research information services and host a management module for teachers and students from the whole school, including literature resources, MOOCs resources, maker information and other resource services. It provides a social space for learning seminars, exchange interactions, cooperation and sharing, and implements new technology training, new tools experiences, hands-on production, new ideas and other practical processes. The various activities carried out by the library include maker quality training, skills training, creative guidance, grant projects, entrepreneurship training camp and so on; all of these activities can promote the deepening of the inherent knowledge structures, and can produce a lot of new knowledge and sublimate the knowledge connotation with learning for practice. 


\subsubsection{The Maker Quality Cultivation Platform}

As the maker movement originated in institutions of higher learning, more than 100 colleges and universities have opened courses on maker quality in the United States, and both early education on information quality and developing education on maker quality are carried out in the universities. Maker quality is not inborn, but needs to be cultivated, including the aspects of maker consciousness, maker morals, maker ability, maker technology, maker spirit, etc. The library cultivates maker quality throughout the whole process of maker services, including cultivating the way students think in practice; insisting on moral standards and the bottom line in the production process, analyzing and solving problems; adopting scientific and technological means in the implementation of innovation production; and cultivating the internal driving force, production values, sharing attitude and other qualities that are expressed in creation and production. Activities such as the "science and information quality elite training camp" and "moot court" are carried out by the library; they are all special examples to apply basic skills to practice, which have great potential to improve makers' professional and comprehensive qualities.

\subsubsection{The Basic Skill Training Platform}

The library makerspace is also the basic skill training platform, which can promote makers to enter, master and control new tools of modernization. It adopts the mode of combining teaching with practice and competition to improve the basic skills of students. It offered technology such as: 3D printing, scanning, IOS system usage, MIUI products and other technical experience; readers can use the nonlinear editing system of video editing space, cameras, printers, scanners, CD writer and other equipment to learn the practice of image processing, audio and video editing, webpage making, statistical analysis, all kinds of programming languages and other skills. The special "cocktail making" training activities for the students in the major of Hotel Management of the tourism college, costume design works exhibition, MOOCs production competition and many other activities have played very important roles in basic skills training. Another example: the "innovative business workshop" activities carried out by the library, use the maker workshop, move the actual project investment to the scene and give lessons and real-time interaction with a large number of cases, so that the teachers and students can have a deeper understanding of business models, to cultivate the reader's business related creative thinking and to practice courage.

\subsubsection{Public Road Show Service Platform}

The makerspace of the library provides teachers and students a platform for teaching reform, scientific research and innovation, presenting works, publicity, displays, investigations, promotion and other activities. The information of works and results can be passed to more people through the publicity and displays in this space, which is a complete communication system and a creative education roadshow platform in the area of innovative and entrepreneurial education. This space does not exist in the traditional library. The "Calligraphy Exhibition", "Fine Arts Works Exhibition", "Photography Exhibition", "Creative Works Competition" and other activities were carried out jointly by the library and other faculties. All these activities publicize the works to more people, and this way not only promote the works and spur the creators themselves to improve, but they also provides common interests of learning, research and inspiration to the creators, and then widely carries out social publicity, communication and promotion. The role of the library makerspace is not only to provide the driving force for teachers and students to develop innovative and entrepreneurial activities, but also the foundation of library makerspaces to assist in innovative and entrepreneurial education. Any library needs this space. 


\subsubsection{The Second Classroom Service Platform}

The makerspace represents a new mode of library modernization service, which provides innovative elements for auxiliary teaching though the library and the reformation of the function of the second classroom. Makerspaces cannot be regarded as being in the same category as the traditional form of the second classroom. Second classroom services in the form of makerspaces offer literature resources, the activity space, modern equipment, service means and so on. The library has realized the new form of services that combines paper information service and digital information service, online service and offline service, and knowledge service and innovation and entrepreneurship education under the concept of makers using a variety of platforms of makespaces. At the same time, the student makers have realized the talent training model that combines professional knowledge learning, practical experience, humanistic quality, comprehensive skills, the innovative consciousness of freshmen and the entrepreneurship ideas of graduates, while teacher makers have enhanced the innovation ability of scientific research and mastered the maker education that is "guiding education." They actively practice innovation and entrepreneurship education, truly become the "guides" of innovation and entrepreneurship education, and set foot on the road of maker education.

\section{CONCLUSION}

Although current libraries are still facing numerous difficulties when it comes to carrying out maker services in certain aspects, including the weak consciousness of innovation and entrepreneurship education, the lack of library talent reserves, the existing personnel not meeting the demand of innovative and entrepreneurial guide work, the lack of special financial support and so on. However, all of these should not become obstacles for libraries to transform and innovate the services for innovation and entrepreneurship education. The development of innovation and entrepreneurship education services of a library are a systematic and long term process; an environment where innovation and entrepreneurship education of the school deeply integrates with professional education cannot be achieved by transforming a few new spaces and carrying out several training sessions. The library should overcome the difficulties in integrating with a traditional space layout and old-fashioned service mode, and strive to build a new model of maker services. As premier Li Keqiang said, innovation and entrepreneurship was a reform which could make us gain equal opportunities to change fate and access the vertical rise. The library is no exception, it should seize the opportunity to implement the transformation, development and vertical rise, build an organic service system of innovation and entrepreneurship and integrate into the school's innovation talent training systems to help schools better realize the innovative talent training objectives. 
Table 1. Partial activities of the library maker space in Shenyang Normal University

\begin{tabular}{|c|c|c|c|}
\hline Practice & $\begin{array}{l}\text { Makerspace } \\
\text { Activities }\end{array}$ & Content & Participants \\
\hline \multirow[t]{4}{*}{$\begin{array}{l}\text { Cultivate innovative and } \\
\text { entrepreneurial quality }\end{array}$} & $\begin{array}{l}\text { Science and } \\
\text { information quality } \\
\text { elite training }\end{array}$ & $\begin{array}{l}10 \text { items, such as scientific research sailing, } \\
\text { knowing the real situation of strength, writing } \\
\text { training, visiting experience and so on }\end{array}$ & $\begin{array}{l}\text { More than } 50 \\
\text { graduate students }\end{array}$ \\
\hline & $\begin{array}{l}\text { "Entrepreneurship } \\
\cdot \text { Enjoy reading" } \\
\text { activities }\end{array}$ & $\begin{array}{l}\text { More than } 10 \text { activities, such as } \\
\text { entrepreneurship auditorium, entrepreneurship } \\
\text { reality show, visiting pioneer park and so on }\end{array}$ & $\begin{array}{l}\text { Over } 10,000 \\
\text { persons in the } \\
\text { whole school }\end{array}$ \\
\hline & $\begin{array}{l}\text { "Keep close } \\
\text { ingenuity, and learn } \\
\text { the way of teacher" }\end{array}$ & $\begin{array}{l}\text { Three steps: reading salon, watching theme } \\
\text { films and sharing the craftsman's spirit }\end{array}$ & $\begin{array}{l}\text { Over } 2,000 \text { persons } \\
\text { in the school }\end{array}$ \\
\hline & $\begin{array}{l}\text { Vocational skills } \\
\text { series training }\end{array}$ & $\begin{array}{l}\text { photography, paper-cutting, tea ceremony, } \\
\text { bartending, calligraphy, costume design, } \\
\text { modeling and so on }\end{array}$ & $\begin{array}{l}\text { Readers } \\
\text { participating of } \\
\text { their own free will }\end{array}$ \\
\hline \multirow[t]{5}{*}{$\begin{array}{l}\text { Lead the entrepreneurial } \\
\text { direction }\end{array}$} & $\begin{array}{l}\text { "Entrepreneurship } \\
\text { Auditorium" first } \\
\text { report }\end{array}$ & $\begin{array}{l}\text { The Opportunities and Challenges of New } \\
\text { Industrial Revolution:entrepreneurial master } \\
\text { and famous entrepreneur Liu Qi }\end{array}$ & $\begin{array}{l}\text { More than } 200 \\
\text { people in literature }\end{array}$ \\
\hline & $\begin{array}{l}\text { Guidance report } \\
\text { on innovation and } \\
\text { Entrepreneurship } \\
\text { outlook }\end{array}$ & $\begin{array}{l}\text { Self-knowledge and Innovation in the Future: } \\
\text { the committee member of Liaoning Provincial } \\
\text { Innovation and Entrepreneurship Education } \\
\text { Steering Committee Wang Xueying }\end{array}$ & $\begin{array}{l}\text { The students about } \\
\text { to graduate }\end{array}$ \\
\hline & $\begin{array}{l}\text { Guidance report } \\
\text { on entrepreneurial } \\
\text { concept }\end{array}$ & $\begin{array}{l}\text { Pragmatic innovation, reliable } \\
\text { entrepreneurship:the researcher of Chinese } \\
\text { Academy of Social Sciences } \\
\text { Yuan Zhizhong }\end{array}$ & Over 300 readers \\
\hline & $\begin{array}{l}\text { The experience } \\
\text { report of } \\
\text { "entrepreneurial } \\
\text { master" }\end{array}$ & $\begin{array}{l}\text { Entrepreneurship is to make life blossom:the } \\
\text { President of Beijing Tourye Tourism Culture } \\
\text { Co., Ltd. Wu Dasheng }\end{array}$ & $\begin{array}{l}\text { Over } 300 \text { students } \\
\text { having no class at } \\
\text { that time }\end{array}$ \\
\hline & $\begin{array}{l}\text { "Entrepreneurial } \\
\text { reality show" }\end{array}$ & $\begin{array}{l}\text { The barilla bookstore of young } \\
\text { entrepreneurs:the CEO of Beijing Haoheng } \\
\text { Zhengtu Aviation Technology Co. Ltd. Chu } \\
\text { Zheng }\end{array}$ & Over 300 readers \\
\hline \multirow[t]{5}{*}{$\begin{array}{l}\text { Build an innovative and } \\
\text { entrepreneurial platform }\end{array}$} & $\begin{array}{l}\text { The innovative and } \\
\text { entrepreneurial } \\
\text { teaching service } \\
\text { platform }\end{array}$ & $\begin{array}{l}\text { study rooms, seminar rooms, studios, } \\
\text { laboratory, works processing room and an } \\
\text { achievement exhibition space }\end{array}$ & $\begin{array}{l}\text { The readers having } \\
\text { projects }\end{array}$ \\
\hline & $\begin{array}{l}\text { The maker quality } \\
\text { cultivation platform }\end{array}$ & $\begin{array}{l}\text { maker consciousness, maker moral, maker } \\
\text { ability, maker technology, maker spirit, etc. }\end{array}$ & $\begin{array}{l}\text { The regular readers } \\
\text { of the school }\end{array}$ \\
\hline & $\begin{array}{l}\text { The basic skill } \\
\text { training platform }\end{array}$ & $\begin{array}{l}\text { 3D printing, scanning, IOS system usage, } \\
\text { editing system, MIUI products and other } \\
\text { technical experience }\end{array}$ & $\begin{array}{l}\text { The total readers by } \\
\text { stages }\end{array}$ \\
\hline & $\begin{array}{l}\text { Public Roadshow } \\
\text { service platform }\end{array}$ & $\begin{array}{l}\text { Teaching reform, scientific research and } \\
\text { innovation, works of speech, publicity, display, } \\
\text { exchange, promotion and other activities }\end{array}$ & $\begin{array}{l}\text { Readers having } \\
\text { works }\end{array}$ \\
\hline & $\begin{array}{l}\text { The second } \\
\text { classroom service } \\
\text { platform }\end{array}$ & $\begin{array}{l}\text { Literature resources, the activity space, } \\
\text { the modern equipment, innovative and } \\
\text { entrepreneurial activities, innovation service } \\
\text { and so on }\end{array}$ & $\begin{array}{l}\text { Shared by all the } \\
\text { readers }\end{array}$ \\
\hline
\end{tabular}




\section{REFERENCES}

New Media Alliance (NMC). (2015). Beijing Open University Project Team. New Media Alliance Horizon Report (2015 Library Edition). Journal of Beijing Radio and Television University, (5), 39-49.

Baidu Encyclopedia. (2016). Craftsmanship. http: //baike.baidu.com/item/\%E5\%B7\%A5\%E5\%8C\%A0\%E7\%B2\% $\mathrm{BE} \% \mathrm{E} 7 \%$ A5\% 9E / 19435895

Heilongjiang People's Government. (2016). Leading cadres should have "craftsmanship" Seventeen on in-depth study and implementation of the spirit of General Secretary Xi Jinping's important speech. http://news.hexun. com/2016-07-08/184822700.html

Ma. (2014). Research on makerspaces construction in the university library. Research on Library, (3), 5-7.

National Library Research Institute. (2015). American Library Association publishes "2015 American Library Status Report". National Library Journal, (3), 59.

Tao, L. (2013). Research on the Construction of a Maker's Room in Library. Journal of Library and Information Service, 72-76(14), 113.

$\mathrm{Wu}$ J. (2016). Toward the third generation of libraries. Library Journal, (6), 4-9.

Zhang \& Cao. (2015). Practical research and enlightenment of typical library makerspaces at home and abroad. Research on Library Science, (22), 9-16.

Yu Wang is a research librarian, the Dean of Shenyang Normal University Library and the Director of the China Society for Library Science. She is a committee member of the fourth session of the Ministry of Education of Higher Institution Intelligence Work Guiding Committee and the vice director of the Society for the Library of Liaoning Province. She is a committee member of China Society for Library Science of user research and service. She has published more than 30 papers, participated in 2 national social science fund projects, and presided over 4 Liaoning province social science key topic items and 4 Liaoning economic and social development topics. Shuli Fan is a graduate school student from Shenyang Normal University. She is the chairman of the Graduate School Student Union and majors in Interpreting and Translation.

Ziling Cheng is a graduate school student from Shenyang Normal University. She majors in Interpreting and Translation. 